\title{
Ontdubbelde handhaving
}

Albertjan Tollenaar, PhD.

Aanbevolen citeerwijze bij dit artikel

Albertjan Tollenaar, PhD., 'Ontdubbelde handhaving', Netherlands Administrative Law

Library, september 2013, DOI: 10.5553/NALL/.000013

\section{Inleiding}

De organisatie van de overheid kan compacter, flexibeler en vooral: goedkoper.

Met dat mantra bevat het Uitvoeringsprogramma compacte rijksdienst een aantal voornemens tot reorganisatie van enkele organen die tot de rijksoverheid behoren. ${ }^{1}$ De reorganisatie die misschien wel de meeste praktische consequenties teweegbrengt, betreft de samenvoeging van toezichthouders in enkele grote rijksinspecties, met het uiteindelijke doel: één alomvattende rijksinspectie. 2

De tussenstap bestaat uit clustering van bestaande rijksinspecties. Op 1 januari 2013 fuseerden de Nederlandse Mededingingsautoriteit (NMa), de Onafhankelijke Post en Telecommunicatie Autoriteit (OPTA) en de Consumentenautoriteit (CA) in een nieuwe Autoriteit Consument en Markt. 3 Een jaar eerder, op 1 januari 2012, werd de Nederlandse Voedsel en Warenautoriteit (NVWA) opgericht als opvolger van de Algemene Inspectiedienst (AID), de Voedsel en Waren Autoriteit (VWA) en de Plantenziektenkundige Dienst (PD). Op dezelfde datum werden de Inspectie Verkeer en Waterstaat en de VROM-inspectie samengevoegd tot één Inspectie Leefomgeving en Transport.

Deze reorganisaties worden verdedigd met het argument dat dat zal leiden tot 'ontdubbeling' 4 'Ontdubbeling' betekent in dit verband dat soortgelijke doelgroepen op dezelfde manier worden bejegend en soortgelijke werkzaamheden binnen één organisatie op dezelfde manier worden uitgevoerd. 5 Werkprocessen worden gestroomlijnd en geüniformeerd, met als gevolg dat (ambtelijke) capaciteit flexibeler kan worden ingezet. Het maakt in een ontdubbelde inspectie niet meer uit wat de achtergrond van de inspecteur is, omdat elke taak op dezelfde wijze wordt uitgeoefend. Het gedroomde gevolg: een reductie van de inspectiedruk voor de ondertoezichtgestelden, een toename van de flexibiliteit en kwaliteitsverbetering binnen de inspecties. ${ }^{6}$

De vraag die in dit artikel centraal staat is in hoeverre deze veronderstelling valide is. Leidt het clusteren van inspecties tot een vergelijkbare bejegening van ondertoezichtgestelden? En aan welke voorwaarden moet eigenlijk worden voldaan om ontdubbeling teweeg te brengen?

Ter beantwoording van deze vragen wordt eerst in paragraaf 2 in algemene zin 
nagegaan wat de handhavingsactiviteiten zijn die 'ontdubbeld' zouden kunnen worden. Dit leidt tot een inventarisatie van de variaties van

handhavingsinstrumenten en variaties ten aanzien van het gebruik ervan. Deze paragraaf mondt uit in enkele veronderstellingen, die ten grondslag liggen aan de reorganisatie van de rijksinspecties en gelezen kunnen worden als condities waaraan voldaan moet worden voor ontdubbeling.

Deze veronderstellingen worden vervolgens getoetst in een casestudy. De casestudy betreft de Inspectie Verkeer en Waterstaat: een inspectiedienst die in 2001 is ontstaan als samenvoeging van verschillende inspectiediensten en inmiddels weer is ondergebracht in een grotere inspectie Leefomgeving en Transport. Paragraaf 3 bevat een overzicht van de bevindingen van de handhavingsinstrumenten en het gebruik daarvan binnen de IVW. In paragraaf 4 wordt geanalyseerd in hoeverre inderdaad binnen de IVW sprake is van een vergelijkbare bejegening van de ondertoezichtgestelden. Paragraaf 5 bevat een conclusie, waarin lessen worden getrokken uit de casus van de IVW voor de nieuwe geclusterde inspecties.

\section{Variaties in handhaving}

\subsection{Toezicht en handhaving: een definitie}

Handhaving en de verwante term 'toezicht' kennen vele vormen en betekenissen. ${ }^{7}$ In de meest algemene definitie heeft toezicht betrekking op alle sociale relaties tussen twee partijen, waarbij de ene partij (de toezichthouder) over machtsmiddelen beschikt om de andere partij (de onder toezicht gestelde) te corrigeren. Toezicht bestaat dan uit het verzamelen en beoordelen van informatie, uitmondend in een besluitvorming over een eventuele interventie om het normconforme gedrag af te dwingen. ${ }^{\mathbf{8}}$ Deze interventie zelf wordt vaak handhaving genoemd.

Deze handelingen kunnen ook juridisch worden geduid. In het juridische discours gaat het bij toezicht om het verzamelen van informatie over de naleving van voorschriften, ${ }^{9}$ waarbij gebruik wordt gemaakt van de bevoegdheden uit hoofdstuk 5 van de Algemene wet bestuursrecht. Handhaving is het meer omvattende begrip, waaronder, naast toezichtshandelingen, ook interventies in de zin van bestuurlijke boetes, of herstelsancties kunnen worden verstaan. ${ }^{\mathbf{1 0}}$ De bestuursrechtelijke handhaving kent ook een strafrechtelijke variant, waarbij de fase van opsporing voorafgaat aan de eigenlijke interventie (strafrechtelijke vervolging, dan wel alternatieve afdoening binnen het strafrecht).

\subsection{Variatie van handhavingsinstrumenten}

Handhavingsinstrumenten zijn in juridisch opzicht bevoegdheden. Het gaat dan om zowel bestuursrechtelijke bevoegdheden die aan het bestuursorgaan of de toezichthouder toekomen, als om strafrechtelijke bevoegdheden, die zijn opgedragen aan de binnen het bestuursorgaan werkzame opsporingsambtenaren. Wanneer men dus wil reconstrueren over welke instrumenten een inspectie beschikt, is het zaak om op zoek te gaan naar de bevoegdheden die door of binnen het bestuursorgaan kunnen worden uitgeoefend.

Voor het bestuursrechtelijke traject gaat het dan enerzijds om de bevoegdheden die samenhangen met het bestuursrechtelijke toezicht op de naleving (afdeling 5.2 Awb) en anderzijds de beslissing over de interventie. Deze interventie varieert van herstelsancties (last onder dwangsom, last onder bestuursdwang), tot punitieve sancties (bestuurlijke boete), ${ }^{\mathbf{1 1}}$ en eventuele bijzondere 
interventies, zoals ontneming van de vergunning of certificaat, of het schrappen van een registratie of aanhouding van een schip. Al deze bevoegdheden zijn in de bijzondere wet opgedragen aan de inspectie of aan een binnen de inspectie werkzame functionaris.

In het strafrechtelijke traject vloeien de instrumenten voort uit de kwalificatie van een gedraging als strafbaar feit in combinatie met de aanwijzing van bijzondere opsporingsambtenaren die belast zijn met de opsporing van die feiten. Het gevolg is dat de opsporingsambtenaar proces-verbaal kan opmaken en eventueel een bestuurlijke strafbeschikking op kan leggen of een transactie aan kan bieden. In dit traject is de inzet van de instrumenten grotendeels afhankelijk van het Openbaar Ministerie. ${ }^{\mathbf{1 2}}$

Van belang is om op te merken dat in de schaduw van deze bevoegdheden ook andere interventies denkbaar zijn. Waarschuwingen, publiceren van toezichtsinsformatie ('naming and shaming') of het doorgeven van informatie aan andere 'stakeholders' zijn daarvan slechts enkele voorbeelden. Het gaat daarbij lang niet altijd om interventies die expliciet zijn gebaseerd op bevoegdheden.

\subsection{Keuzes bij het gebruik van handhavingsinstrumenten}

Gelet op de variatie aan handhavingsinstrumenten rijst de vraag op welke wijze deze instrumenten worden gebruikt. Dit is een empirische vraag waarnaar verschillend onderzoek is verricht. Dit onderzoek grijpt aan op verschillende niveaus: van de keuze van de inspecteur die moet kiezen tussen optreden of nietoptreden en daarbij de keuze heeft tussen de verschillende instrumenten, tot de strategie van de organisatie waarin deze inspecteur werkt en waarin deze keuzes worden voorgeschreven.

Het individuele niveau spreekt wellicht het meest tot de verbeelding. De inspecteur is dan een street-level bureaucrat die gebruik maakt van zijn eigen ambtelijke beleidsvrijheid.13 Deze beleidsvrijheid heeft betrekking op tal van kleine en grotere keuzes: over het wel of niet zien van een overtreding, over het wel of niet kwalificeren van een feit als overtreding, maar ook over de keuze tussen advies of handhaving.

Bij al deze keuzes ontwikkelt de inspecteur een handhavingsstijl. ${ }^{\mathbf{4}}$ Handhavingsstijlen ontstaan als gedeelde voorkeur op de werkvloer ten aanzien van de wijze waarop de vele instrumenten moeten worden gebruikt. ${ }^{\mathbf{1 5}}$ Inspecteurs hebben een modus operandi, delen deze en spreken elkaar daarop aan - als professionals onder elkaar. ${ }^{\mathbf{1 6}}$ Aalders duidt de handhavingsstijl aan met de term interpretatieregels: sociale regels binnen een groep, over de interpretatie en toepassing van andere, op schrift gestelde regels. ${ }^{17}$ May \& Burby noemen deze handhavingsstijl een handhavingsfilosofie: een onderliggend idee over de wijze waarop inspecteurs hun taken zouden moeten vormgeven. ${ }^{\mathbf{1 8}}$ De handhavingsfilosofie verschilt bijvoorbeeld van een inspecteur gevaarlijke stoffen tot een inspecteur die toezicht houdt op de kinderopvang en van de inspecteur die toezicht houdt op de farmaceutische industrie tot de bouwinspecteur. Het verschil uit zich in de keuze welke normoverschrijdingen men belangrijk vindt, waar een 'goede' naleving van de regels aan moet voldoen. De handhavingsfilosofie kan leiden tot kleine gedoogbeslissingen op de werkvloer: normoverschrijdingen waarvan de inspecteur oordeelt dat deze niet schadelijk is voor het door hem en zijn sociale context geïdentificeerde algemene belang.

Van een geheel andere orde zijn de strategische keuzes die door de organisatie 
als geheel worden gemaakt. Dit zou men de handhavingsstrategie kunnen noemen. De handhavingsstrategie bevat keuzes over de inzet van schaarse capaciteit en de inschatting van eventuele risico's bij het niet-gebruiken van handhavingsinstrumenten voor het functioneren van de organisatie als zodanig. Vaak treft men de handhavingsstrategie aan in documenten die worden vastgesteld op een strategisch niveau van ambtelijke of politieke gezagsdragers. ${ }^{19}$ Het beleid heeft vaak de inzet van middelen en bevoegdheden als onderwerp en regelt soms afstemming tussen andere actoren buiten de inspectie. Ook de keuzes in dit handhavingsbeleid hebben gevolgen voor de wijze waarop handhavingsinstrumenten wel of niet worden gebruikt.

\subsection{Premissen ten aanzien van ontdubbeling}

De verwachting is dat het samenvoegen van inspecties leidt tot een uniforme aanpak, die voorspelbaar is voor de ondertoezichtgestelde en waarbij inspecteurs inwisselbaar zijn en op elk beleidsveld inspectietaken kunnen verrichten. Deze redenering is gebaseerd op ten minste twee premissen. De eerste premisse betreft de variatie van het instrumentarium. Hoe meer deze instrumenten uiteen lopen, hoe minder eenvoudig het zal blijken te zijn om de handhavingsorganisatie te uniformeren en te integreren. Dit betekent dat de handhavingsinstrumenten in de verschillende wetten die door de 'ontdubbelde' inspectie moeten worden gehandhaafd, niet of althans niet te zeer moeten verschillen. De uniformiteit van de handhavingsinstrumenten kan worden vastgesteld aan de hand van de wetgeving waarin die instrumenten zijn neergelegd.

De tweede premisse betreft het gebruik van de handhavingsinstrumenten. In een ontdubbelde inspectie wordt op dezelfde wijze gebruik gemaakt van het instrumentarium. Dat vergt een uniforme, geëxpliciteerde handhavingsstrategie en een uniforme handhavingsstijl. Alleen dan is immers sprake van een serieuze ontdubbeling, waarbij het er eigenlijk niet toe doet met welke inspecteur of onderdeel van de inspectie de ondertoezichtgestelde te maken heeft.

\section{Case study: handhaving door de IVW}

\subsection{De IVW als object van onderzoek}

De Inspectie Verkeer en Waterstaat (IVW) is inmiddels samengevoegd met de VROM-inspectie tot de Inspectie Leefomgeving en Transport. De IVW zelf was echter ook al een samensmelting van verschillende inspecties. In 2001 fuseerden Scheepvaartinspectie, Rijksverkeersinspectie, Rijksluchtvaartinspectie, Korps controleurs gevaarlijke stoffen en onderdelen van het Ministerie van V\&W tot de IVW. Later werd Railned hieraan toegevoegd.

De IVW is daarmee een case die kan illustreren in hoeverre 'ontdubbeling' wordt gerealiseerd. De IVW was werkzaam op verschillende toezichtsdomeinen, die allen verband hielden met vervoer en waterstaat. Een toezichtsdomein wordt gezien als een 'branche', dat wordt afgebakend door een specifieke activiteit of specifieke groep normadressaten. ${ }^{20}$

De casestudy beperkt zich tot de handhaving op de toezichtsdomeinen die verband houden met vervoer, meer concreet: de binnenvaart, de zeevaart, het goederenvervoer over de weg, het bus- en taxivervoer, de luchtvaart en ten slotte het spoorvervoer. ${ }^{\mathbf{2 1}}$ In deze casestudy is onderzocht in hoeverre inderdaad sprake is van ontdubbeling binnen de samengevoegde inspectiedienst. ${ }^{\mathbf{2 2}}$

\subsection{Variatie van handhavingsinstrumenten}


De IVW heeft in elk domein vergelijkbare instrumenten tot haar beschikking. Dat is ook niet zo vreemd, omdat een aantal wetten (Arbeidstijdenwet, Arbeidsomstandighedenwet) door de IVW wordt gehandhaafd in alle domeinen. Maar ook voor de wetten die wel domein-specifiek zijn, geldt dat deze een vergelijkbare vormgeving met een vergelijkbaar handhavingsinstrumentarium hebben. In vrijwel alle gevallen gaat het om een aantal bestuursrechtelijke instrumenten (aanwijzing als toezichthouder, en de bevoegdheid om bestuursdwang uit te oefenen) al dan niet in combinatie met strafrechtelijke instrumenten (opsporingsbevoegdheden voor de inspecteurs die als bijzondere opsporingsambtenaar zijn aangewezen).

De verschillen zitten vaak in de details. Zo is de bevoegdheid de ene keer opgedragen aan de minister die deze heeft gemandateerd aan de inspecteurgeneraal of toezichthouders van de IVW, terwijl in andere gevallen een rechtstreekse attributie plaatsvindt aan 'de ambtenaren van de Scheepvaartinspectie', die als zodanig niet meer bestaat. ${ }^{\mathbf{2 3}}$

Een groter verschil betreft de mogelijkheid om een bestuurlijke boete op te leggen. Deze bevoegdheid is weliswaar opgenomen in de voor alle domeinen relevante Arbeidsomstandighedenwet en Arbeidstijdenwet, maar geldt daarnaast ook als handhavingsinstrument voor de handhaving van de Binnenvaartwet. Voor het overige bestaat het handhavingsinstrumentarium voor het domein Binnenvaart, evenals het domein Scheepvaart, uit het toezicht en de handhaving van certificaten. In het laatste domein geldt echter weer de bijzondere bevoegdheid om schepen 'aan te houden'. Deze bevoegdheid lijkt sterk op het uitoefenen van bestuursdwang, maar wordt desondanks expliciet niet als bestuursdwang aangemerkt, omdat het relevante deel van de Awb niet van toepassing wordt verklaard.

De handhaving van de regelgeving over het vervoer van goederen over de weg draait vooral om het toezicht op de naleving van beladingsvoorschriften (Wet wegvervoer goederen en Wet vervoer gevaarlijke stoffen). Voor de handhaving van deze voorschriften is zowel voorzien in opsporingsbevoegdheden als in een bestuursrechtelijk instrumentarium gericht op het toezicht op de naleving van certificaten en het uitoefenen van bestuursdwang. De Wet wegvervoer goederen bevat een specifieke bevoegdheid om met een 'mechanisch hulpmiddel' transport daadwerkelijk stil te zetten (art. 5.4 Wet wegvervoer goederen). Deze dwangbevoegdheid bestaat naast een algemene bestuursdwangmogelijkheid. In zoverre beschikt de IVW over twee dezelfde bevoegdheden. Het verschil is echter dat deze bijzondere bevoegdheid rechtstreeks wordt opgedragen aan de opsporingsambtenaren, die ook zijn belast met de opsporing van strafbare feiten, terwijl de uitoefening van de bestuursdwangbevoegdheid niet zo ver is gemandateerd.

De regelgeving die het bus- en taxivervoer beheerst, bestaat voornamelijk uit de vergunningsplicht op grond van de Wet personenvervoer 2000, die bestuursrechtelijk wordt gehandhaafd door de intrekking van de vergunning of het uitoefenen van bestuursdwang.

In de luchtvaartsector is het voornaamste wettelijke handhavingsinstrument het schorsen of intrekken van certificaten. Elke schakel in de luchtvaart (van bouw van luchtvaartuigen, tot onderhoud en van luchtvaartmaatschappijen tot toeleveranciers) dient over een certificaat te beschikken. Het toezicht op de aanwezigheid van certificaten, in combinatie met de mogelijkheid om deze tijdelijk te schorsen of definitief in te trekken, vormt het voornaamste handhavingsinstrumentarium. Daarnaast is voorzien in de mogelijkheid om een bestuurlijke boete op te leggen en wordt een aantal voorschriften strafrechtelijk gehandhaafd. Bijzonder is voorts artikel 11.27 Wet luchtvaart dat de plicht voor 
de Minister bevat om opgelegde bestuurlijke boetes of bestuursdwangbeschikkingen te publiceren.

Ook in het spoorvervoer is elke schakel gecertificeerd en is het handhavingsinstrumentarium primair gericht op de aanwezigheid van deze certificaten. Daarnaast beschikt de minister (en dus: de IVW) over de mogelijkheid om een bestuurlijke boete op te leggen voor de handhaving van de Spoorwegwet en beschikt het bestuursorgaan over bijzondere dwangbevoegdheden in de vorm van het sluiten van baanvakken.

\section{Tussenconclusie}

De tussenconclusie is dat de IVW over een zeer breed arsenaal aan handhavingsinstrumenten beschikt. Grosso modo beschikt de IVW in elk domein over vergelijkbare interventies: zowel bestuursrechtelijke als strafrechtelijke.

De verschillen zijn beperkt tot enkele bijzondere interventies, zoals de bestuurlijke boete die niet altijd tot de mogelijkheden behoort, en de bijzondere instrumenten in de domeinen - zoals het aanhouden van schepen of het stilzetten van transport. Voor deze bijzondere instrumenten geldt echter dat deze grote gelijkenis hebben met bijvoorbeeld de last onder bestuursdwang, waarmee de overtreding immers ook door feitelijk handelen wordt beëindigd.

\subsection{Gebruik handhavingsinstrumenten}

Gelet op het brede arsenaal aan handhavingsinstrumenten, en vooral het gegeven dat de IVW in veel gevallen over vergelijkbare instrumenten beschikt, rijst de vraag hoe handhaving in de praktijk vormgegeven wordt. Welke van deze instrumenten worden gebruikt, en waarom? Het beantwoorden van deze vraag leidt tot een beschrijving van de handhavingsstrategie en de handhavingsfilosofie en handhavingsstijlen binnen de IVW en de afzonderlijke toezichtsdomeinen. De beschrijving van de filosofie en handhavingsstijl is gebaseerd op de interviews en enkele cases die met de toezichthouders zijn besproken.

\section{Handhavingsstrategie}

De handhavingsstrategie kan worden afgeleid uit een tweetal documenten: het Meerjarenplan uit 2010-2014 en een nota, genaamd 'Eindrapport Inventarisatie Interventies' uit 2007.

Uit het meerjarenplan volgt dat de IVW zich dienstbaar wil opstellen tegenover de ondertoezichtstaanden. ${ }^{\mathbf{2 4}}$ Dit houdt in dat voorlichting en informatie wordt gegeven over de van toepassing zijnde wet- en regelgeving. Het toezicht is gericht op 'vertrouwen tenzij'. Hieruit vloeit voort dat de inspectie van plan is een 'risicoselectiesysteem' te ontwikkelen. Convenanten vormen daarbij een belangrijk instrument, naast fysieke inspecties, audits, bedrijfsinspecties, steekproefcontroles en acties (landelijk, regionaal of themagericht). Onder het kopje 'opsporing' worden in dit plan alle interventies genoemd van bestuursrechtelijke boetes, een last onder dwangsom, bestuursdwang, het intrekken van de vergunning tot strafrechtelijke maatregelen. In het laatste geval wordt de handhaving overgedragen aan de politie en het Openbaar Ministerie. Er wordt geen duidelijke keuze voorgeschreven.

In het 'Eindrapport Inventarisatie Interventies' wordt onderscheid gemaakt tussen 'de groep die geneigd is tot naleven en de groep die dat niet is'. Dit leidt tot een onderscheid in keuzes ten aanzien van de daadwerkelijke interventie, 
waarbij strikter wordt opgetreden (sluiting, intrekken vergunning en dergelijke) naarmate de neiging tot naleving kleiner is. Een ander belangrijk criterium is de aanwezigheid van risicovolle of gevaarlijke situaties.

En ten slotte wordt benadrukt dat bij het gebruik van de instrumenten het escalatieprincipe moet worden gehanteerd, waarbij het uitgangspunt wordt gehanteerd 'zacht waar het kan, hard waar het moet'.

\section{Handhavingsstijl}

Binnen de IVW lijkt de strategie, net als de handhavingsinstrumenten, tamelijk uniform. Er zijn althans geen grote verschillen benoemd per domein. De volgende vraag is echter hoe deze strategie uitwerkt in concrete beslissingen van inspecteurs. Het gaat dan om de handhavingsstijl. Als stijl zou men een de coöperatieve of faciliterende enerzijds kunnen onderscheiden van de punitieve of repressieve stijl anderzijds. ${ }^{25}$ Deze indeling maakt gebruik van de piramide van Ayres en Braithwaite (1992) die uitgaat van een escalatieladder: van overtuigen, instrueren en adviseren (behorend tot de faciliterende handhaving) tot het bestraffen, intrekken van een vergunning of stilleggen van een onderneming (repressief dan wel punitief). Tussen deze twee uitersten zitten mildere varianten (zwak repressief en zwak coöperatief). Dit uit zich in keuzes als 'naming and shaming', waarschuwen en het opleggen van een last onder dwangsom. ${ }^{26}$

\section{Sterk repressief}

De eerste handhavingsstijl laat zich typeren als 'sterk repressief'. Deze stijl is met name aangetroffen bij de handhaving van de Wet vervoer gevaarlijke stoffen voor vrijwel alle domeinen en meer specifiek binnen de domeinen Goederenvervoer over de weg en Bus/taxi voor de bijzondere wetten in die domeinen. De constatering van een overtreding leidt tot een proces-verbaal, waarna ter plekke een transactievoorstel wordt gedaan in overleg met het Openbaar Ministerie.

Hoewel naast deze instrumenten ook andere bestuursrechtelijke instrumenten bestaan (zoals het intrekken van een certificaat), blijven die instrumenten onbenut. Ook wordt geen bestuursdwang uitgeoefend. In plaats daarvan wordt consequent - gebruik gemaakt van een strafrechtelijke variant, waarbij bijvoorbeeld een maatregel wordt opgelegd om overbelading af- of over te laden. Deze maatregel is gebaseerd op artikel 8 van de Wet op de economische delicten en lijkt sterk op de wijze waarop de KLPD handhaaft.

Een subvariant betreft het gebruik van interventies die een grote schade toebrengen aan de ondertoezichtgestelde, waarna deze - zonder de overtreding te bediscussiëren - tot naleving overgaat. Deze variant is aangetroffen in de domeinen Scheepvaart, voor wat betreft de port state control (oftewel: de fysieke controle van buitenlandse schepen) en Goederenvervoer over de weg. In beide domeinen beschikt de inspectie over een bijzondere bevoegdheid waarmee het transport wordt stilgelegd. ${ }^{27}$ De economische schade die dat teweegbrengt resulteert erin dat de overtreder, of althans degene die ter plekke het transport verzorgt, doorgaans geneigd is om de overtreding zo snel mogelijk te beëindigen.

\section{Zacht repressief}

De tweede variant kan worden aangeduid als 'zacht repressief'. Deze variant is aangetroffen in de domeinen waar wordt gehandhaafd met het oog op de bestuurlijke boete. Het gaat dan om handhaving in het domein Binnenvaart (Binnenvaartwet) en in de andere domeinen waar serieus werk wordt gemaakt 
van de handhaving van de Arbeidstijdenwetgeving. ${ }^{28}$ De bestuurlijke boete volgt op het opstellen van een boeterapport door de inspecteur. De beslissing over het al dan niet opleggen van een bestuurlijke boete wordt genomen door een aparte afdeling binnen IVW: het Bureau Boetes. Daarbij geldt als interne afspraak dat een boeterapport moet worden opgesteld indien een overtreding wordt geconstateerd. Dat is meteen ook het repressieve karakter van de handhavingsstijl: er is geen ruimte voor onderhandeling of een nadere analyse van de oorzaken van de overtreding omdat de inspecteur de opdracht heeft een boete op te leggen.

Toch blijkt de praktijk vindingrijker. Uit de interviews blijkt dat inspecteurs een eigen stijl ontwikkelen waarmee de officiële lijn wordt ontdoken. Een voorbeeld is de voorwaardelijke bestuurlijke boete. Indien een boetewaardige overtreding van kleine omvang wordt geconstateerd wordt met de overtreder afgesproken dat deze overtreding wordt hersteld binnen een bepaalde termijn. Blijft herstel achterwege, dan wordt alsnog boeterapport opgemaakt en doorgezonden. In zo'n geval vindt hercontrole op afstand plaats, doordat de overtreder een foto maakt van de legale situatie en deze dan opstuurt.

\section{Zwak coöperatief}

Een derde handhavingsstijl kan worden aangeduid als 'zwak coöperatief'. In deze variant valt de papieren controle of de auditing. Naast of in plaats van fysieke controle van de voertuigen of bestuurders van die voertuigen, richt de inspectie zich tot de opdrachtgevers (eigenaars, werkgevers, rederijen) en wordt in de administratie nagegaan of het risico bestaat dat een regel wordt overtreden. Een voorbeeld is de vlagstaatcontrole in het domein Scheepvaart. Deze vlagstaatcontrole richt zich op rederijen die in Nederland gevestigd zijn. Op basis van de administratie van de rederijen wordt vastgesteld wat de rederij eraan heeft gedaan om de regels na te leven. Een goede borging van de naleving van de publiekrechtelijke regels kan zelfs resulteren in een convenant. Een vergelijkbare handhavingsstijl is aangetroffen in het domein Bus/taxi voor wat betreft de busvervoerders en enkele grote taxibedrijven. In deze branche heeft de goedkeuring door de IVW directe economische waarde, omdat mogelijke opdrachtgevers (reisorganisaties) op basis daarvan gebruik maken van de diensten van de ondertoezichtgestelden.

\section{Sterk coöperatief}

Een laatste stijl kan worden aangeduid als 'sterk coöperatief'. Deze stijl is aangetroffen in de domeinbraiten Luchtvaart en Spoor. Deze domeinen kenmerken zich door een hoge risicobeleving van de ondertoezichtgestelde en een grote informatieachterstand van de toezichthouder. Of een vliegtuig veilig is, kan immers bij een fysieke controle onmogelijk precies worden nagegaan. De toezichthouder moet dan wel vertrouwen op de werking van de interne veiligheidssystemen, waarbij de publiekrechtelijk voorgeschreven certificaten een belangrijke rol vervullen. Elke schakel, elke toeleverancier en elk onderhoudsbedrijf heeft een certificaat nodig. Het toezicht van de inspectie richt zich op de interne borging binnen de bedrijven, met als uiterst dreigement het tijdelijk schorsen of intrekken van het certificaat. Deze sanctie is echter tevens het economische doodsvonnis van het bedrijf, dat immers vaak uitsluitend economische activiteiten verricht die onder dat certificaat vallen. Het gevolg hiervan is dat het dreigen met schorsing of intrekking, in de vorm van een zogenaamd 'slechtnieuwsgesprek' als een voldoende stevige interventie wordt gevonden.

Daarbij worden eventuele gevaarzettende situaties, bijvoorbeeld ten aanzien van 
het spoor, opgelost door direct contact tussen de inspecteurs en de verantwoordelijke functionarissen binnen Prorail. Dit houdt tevens verband met de bijzondere positie van Prorail (overheidsbedrijf) en de inspecteurs die deels een gelijke achtergrond hebben.

Overigens ondersteunt het feit dat in de domeinen Spoor en Luchtvaart ten tijde van het onderzoek geen bijzondere opsporingsambtenaren werkzaam waren, de typering als van de handhavingsstijl als 'coöperatief'. Dit maakt het immers onmogelijk om op te treden als opsporingsambtenaar, gericht op een punitieve interventie. $^{29}$

\section{Tussenconclusie}

Eerder is geconstateerd dat het instrumentarium, enkele uitzonderingen daargelaten, redelijk uniform is. Dat geldt ook nog wel voor de handhavingsstrategie, zoals deze is opgeschreven in het Meerjarenplan uit 2010 en het 'Eindrapport Inventarisatie Interventies' uit 2007. De handhavingsstijlen op de werkvloer vertonen echter wel grote verschillen. Deze verschillen doen zich voor tussen de domeinen en soms binnen de domeinen. Soms is sprake van een meer coöperatieve stijl, dan weer van een meer repressieve stijl. In de onderstaande tabel wordt de verdeling van aangetroffen stijlen kort weergegeven.

ITypering handhavingsstijlen per toezichtsdomein
Domein

\section{typering handhavingsstijl}
Binnenvaart
zacht repressief
Scheepvaart
sterk repressief ten aanzien van port state controlzwak coöperatief ten aanzien van vlagstaatcontrole

Goederenvervoer

over de weg

sterk repressief

Bus/taxi

sterk repressief ten aanzien van Arbeidstijdenwet en Wet

$\begin{array}{ll} & \text { van busvervoer. } \\ \text { Luchtvaart } & \text { sterk coöperatief } \\ \text { Spoor } & \text { sterk coöperatief }\end{array}$

\section{Analyse}

De variatie binnen de IVW leidt tot de vraag welke factoren leiden tot een repressief gebruik van de handhavingsinstrumenten of juist tot een coöperatieve houding van de inspecteurs. Deze factoren zijn uiteindelijk de factoren die leiden tot verschil binnen de inspectie en die dus in de weg staan aan een volledige ontdubbeling van het toezicht.

\section{Proportionele interventie}

Allereerst valt op dat in een aantal gevallen de in de wet of in het beleid geformuleerde plicht tot handhaven wringt met de door de inspecteur gevoelde behoefte aan overleg en nadere afspraken. Juist waar de wetgever geen beleidsvrijheid verschaft en dwingt tot optreden, blijkt in de praktijk wel degelijk sprake van een handhavingsstijl die juist coöperatiever is dan de wetgever voor ogen had. In zo'n geval ontstaan alternatieve methoden waarmee de interventie wordt afgestemd op de ernst van de overtreding. Een voorbeeld betreft de 
voorwaardelijke boete op grond van de Binnenvaartwet, of de coulanceregelingen in de boetecatalogi voor overtredingen van de Arbeidstijdenwet. In beide gevallen had een boete moeten worden opgelegd, maar wordt bij een kleine overtreding volstaan met een waarschuwing.

\section{Meewegen gevolgen handhavingsinstrumenten}

De proportionele interventie houdt verband met de waardering van de consequenties van een interventie. De gevolgen van het instrument spelen altijd een rol bij de keuze om al dan niet handhavend op te treden. Bestuursdwang waarmee een economische activiteit wordt stilgelegd (vaarverbod, startverbod) wordt daarom zoveel mogelijk vermeden.

Dit houdt ook verband met de mogelijke consequenties in de zin van aansprakelijkheid indien de aanhouding of het startverbod naderhand onterecht blijkt. Juist in de domeinen waar men uitsluitend beschikt over zeer zware instrumenten, heeft men behoefte aan minder harde instrumenten, zoals de bestuurlijke boete of de last onder dwangsom. Met name de last onder dwangsom biedt een zeer effectief middel om met de dwangsom een evenredige prikkel te construeren waardoor de overtreder wordt gedwongen om de overtreding te beëindigen.

\section{Onbekendheid met het volledige instrumentarium}

Deze zachte instrumenten zijn in veel gevallen wel degelijk mogelijk. In veel domeinen is wel voorzien in een bestuursdwangbevoegdheid en daarmee met de mogelijkheid om een last onder dwangsom op te leggen (art. 5:31 Awb). Deze mogelijkheid is echter niet doorgedrongen op de werkvloer en wordt dus ook niet opgelegd..$^{\mathbf{3}}$

Met name in de domeinen waarin inspecteurs veelal optreden met uitoefening van strafrechtelijke bevoegdheden blijken deze bestuursrechtelijke mogelijkheden onbekend. Omdat nu eenmaal altijd strafrechtelijk wordt opgetreden, worden maatregelen opgelegd op grond van de Wet op de economische delicten, terwijl een bestuursdwang of dwangsomuitoefening soms veel effectiever en eenvoudiger kan zijn. Als voorbeeld kan worden gewezen op de handhaving van de Wet wegvervoer goederen, waarbij inspecteurs gebruik maken van de bevoegdheid uit artikel 5.4 Wet wegvervoer goederen om met mechanische hulpmiddelen vervoer te beletten, maar vervolgens op het interpretatieprobleem stuiten dat zij moeten bepalen wat 'een mechanisch hulpmiddel' is. Aan de ruimere bestuursdwangbevoegdheid, die niet beperkt is tot het gebruik van een 'mechanisch hulpmiddel', wordt daarbij echter niet gedacht.

\section{Ontwijken van formele procedures}

Het ontbreken van kennis over de precieze grondslag van het handelen heeft ook tot gevolg dat inspecteurs zo veel mogelijk formele procedures ontwijken. Handhaving vindt in veel gevallen plaats zonder dat daaraan een formeel besluit ten grondslag ligt. In het domein Spoor is dit nog wel het meest zichtbaar: de mondelinge bestuursdwang wordt nooit op schrift gesteld, maar blijkt wel een effectieve beëindiging van de overtreding. Deze interventie wordt overigens ook niet betwist door de ondertoezichtgestelde. 
Een verbijzondering van het vermijden van formele procedures betreft het vermijden van de strafrechtelijke procedure. Het maakt nogal wat uit of de inspecteur kiest voor een strafrechtelijk traject of een bestuursrechtelijk traject. Hoewel de meeste van de onderzochte wetten in beide mogelijkheden voorzien, is er in de handhavingspraktijk een sterke voorkeur voor of een strafrechtelijk of een bestuursrechtelijk traject. Deze voorkeur verschilt per domein en binnen een domein per wet.

Het algemene beeld is dat de IVW-inspecteurs zoveel mogelijk vermijden handhavend op te treden via het strafrechtelijke circuit en dus als opsporingsambtenaar een proces-verbaal opstellen, waarna - eventueel strafrechtelijke vervolging kan plaatsvinden (al dan niet afgedaan via een transactie). Het vermijden van het strafrechtelijke instrumenten houdt verband met de omslachtigheid die men ervaart bij het gebruiken van dit type instrument. De overtreding leidt dan tot een proces-verbaal, waarna overleg plaats moet vinden met het OM over het transactiebedrag. Doorgaans ontbreekt bij het OM de exacte expertise over de geconstateerde overtredingen, zodat deze procedure als omslachtig en overbodig wordt gezien.

In het geval er niet een onmiddellijk transactievoorstel wordt gedaan, en de overtreding vanuit het perspectief van de IVW eindigt met het opstellen van een proces-verbaal, is de uitkomst zo mogelijk nog onbevredigender: de overtreding kan worden geseponeerd en in veel gevallen tast het IVW in het duister over het vervolgingsresultaat.

In de wetten die wel strafrechtelijk worden gehandhaafd (Wet wegvervoer goederen, Wet vervoer gevaarlijke stoffen) heeft het OM voorzien in gedetailleerde instructies. Op deze terreinen is een goed ontwikkelde handhavingspraktijk ontstaan, waarbij de genoemde bezwaren bij het gebruiken van het strafrechtelijke instrumentarium, zich niet voordoen.

\section{Naleefgedrag door normadressaten}

Het zijn niet alleen factoren binnen de inspectie die van invloed zijn op het al dan niet gebruiken van het instrumentarium. Ook de kennis over het naleefgedrag is van invloed. ${ }^{\mathbf{3 1}}$ Naarmate het naleefgedrag minder groot is, wordt het gebruikte handhavingsinstrumentarium repressiever van aard: lik-op-stuk, boetes, stilleggen. Dit is met name waargenomen in de domeinen goederenvervoer over de weg en bus/taxi, waar het gaat om de handhaving van de arbeidstijdenwetgeving of de naleving van de vergunningplicht (taxivervoer). Indien het naleefgedrag over het algemeen groter is, wordt volstaan met het gebruik van lichtere instrumenten. Dit leidt tot overleg, een 'slechtnieuwsgesprek' en in het uiterste geval verscherpt toezicht. In deze bewoordingen is hetzelfde type interventie aangetroffen: met de overtreder wordt geconstateerd wat de overtreding is, wordt nagegaan hoe deze overtreding kan worden beëindigd en worden afspraken gemaakt over de termijn waarbinnen de overtreding zal zijn beëindigd. In een doelgroep die over het algemeen geneigd is tot normconform gedrag, wordt vaker gebruik gemaakt van dit type interventies die als zodanig niet in de wet zijn gereguleerd en daar eigenlijk aan voorafgaan. Er is in dit geval geen behoefte aan een formeel besluit, met bijvoorbeeld een aanzegging van een last onder dwangsom.

\section{Belang van de goede relatie met de onder toezichtgestelde}

Een reden om na constatering van een overtreding juist niet te interveniëren, houdt verband met het belang dat men hecht aan de goede relatie met de onder toezichtgestelde. De effectiviteit van het toezicht is in een aantal domeinen sterk 
afhankelijk van de transparantie van het domein, bestaande uit de informatie die de onder toezichtgestelden zelf melden. Dit is met name het geval in de domeinen waarin een acuut veiligheidsbelang speelt, zoals Luchtvaart en Spoorvervoer. In deze domeinen past het niet om degene die een probleem meldt te 'belonen' met een bestuurlijke boete of proces-verbaal omdat dat probleem duidt op het niet naleven van een norm.

In andere domeinen heeft het toezicht vooral een ander doel, namelijk het beschermen van een markt, het creëren van een 'level playing field'. Hierbij kan met name worden gedacht aan het toezicht op de vergunningen op grond van de Wet personenvervoer 2000 en de Wet wegvervoer goederen. Overtredingen van deze regelgeving zijn relatief eenvoudig vast te stellen en de IVW hoeft in principe niet te streven naar een goede relatie met de normadressaten om een verder gelegen veiligheidsdoel te bereiken.

\section{Handhaving in ketens}

In sommige gevallen wordt in de handhavingsstijl gebruik gemaakt van het gegeven dat activiteiten waarop toezicht wordt gehouden, zich in een keten tot elkaar verhouden. Veilige luchtvaart wordt bijvoorbeeld bepaald door de ontwerper van vliegtuigonderdelen, degene die de onderdelen fabriceert, de leverancier, de monteur en uiteindelijk de piloot, diens opleidingsinstituut en niet te vergeten: de luchtvaartmaatschappij die de vlucht organiseert. In veel domeinen kunnen vergelijkbare ketens worden geconstrueerd, zij het dat deze keten soms beperkt is tot die van de werkgever (busmaatschappij) en werknemer (chauffeur). In het geval er een 'keten' kan worden geconstrueerd, wordt gezocht naar instrumenten om op meer plekken in de keten te interveniëren. De bedrijfscontroles en audits zijn daarvan voorbeelden, maar ook 'naming and shaming' (bekend maken van toezichtsinformatie bij mogelijke afnemers), of interventies gericht op de keurmerken vallen onder het 'handhaven in ketens'. In een aantal gevallen is deze keten juist niet te construeren, omdat de overtreder zijn opdrachtgever in bescherming wil nemen om geen toekomstige opdrachten mis te lopen (goederenvervoer over de weg). Met name in de domeinen met een zeer 'open' groep normadressaten (individuele taxichauffeurs) ontbreken deze verbanden en richt de handhaving zich noodgedwongen op het individuele product of de individuele gedraging. Dit leidt als vanzelf tot een meer repressieve handhavingsstijl dan in het geval de handhaving zich op de hele keten kan richten.

\section{Conclusie}

De centrale vraag die aan het begin van dit artikel werd opgeworpen is of het clusteren van inspecties inderdaad leidt tot een vergelijkbare bejegening van ondertoezichtgestelden. Met de casus van de Inspectie Verkeer en Waterstaat op het netvlies, kan worden geconcludeerd dat het antwoord negatief moet luiden. Samenvoegen van inspecties leidt niet automatisch tot ontdubbeling van de wijze waarop de inspectie verschillende ondertoezichtgestelden bejegent.

Weliswaar beschikt de inspectie vaak over ruime bevoegdheden en vergelijkbare instrumenten (uitzonderingen daargelaten). Maar dat betekent niet dat het gebruik ervan overeenstemt. In zoverre bevestigt de case study eerder onderzoek van bijvoorbeeld May \& Burby (1998) en Aalders (1987): handhaving en toezicht hangen niet zozeer af van het instrumentarium, maar vooral van de keuzes die op de werkvloer worden gemaakt ten aanzien van het gebruik van die instrumenten (de handhavingsstijlen).

Dat roept de vraag op of het mogelijk is om voorwaarden te creëren waarin 
inderdaad sprake is van ontdubbeling, oftewel: hoe zouden handhavingsstijlen kunnen worden geüniformeerd? Uit de analyse van de handhavingsstijlen volgen verschillende factoren. Enkele van de factoren zijn eenvoudig te beïnvloeden. Dat geldt met name voor de onbekendheid op de werkvloer met het volledige handhavingsinstrumentarium. Deze onbekendheid is eenvoudig op te lossen door handhavingsbeleid of instructies op te stellen.

Ook de zoektocht naar proportionele interventies kan relatief eenvoudig worden opgelost, door in wetgeving oog te hebben voor de afweging die in individuele gevallen wordt gemaakt. In plaats van een boeteplicht dient dus altijd gekozen te worden voor een beleidsvrijheid bij het opleggen van een boete, zodat de inspecteur een mogelijkheid heeft om te volstaan met een waarschuwing. Het formuleren van een te streng instrumentarium resulteert immers alleen maar tot non-gebruik of creatief gebruik dat niet wordt geregistreerd in de schaduw van het recht.

Andere factoren zijn echter minder goed te beïnvloeden. Dat betreft dan de soorten normen en typen ondertoezichtgestelden. Juist deze factoren vormen obstakels voor een daadwerkelijke ontdubbeling van de handhaving. Naarmate de normen vager zijn en de inspecteur voor de naleving van die normen meer afhankelijk is van de informatie van de ondertoezichtgestelde, ontstaat min of meer noodzakelijkerwijs een meer coöperatieve handhavingsstijl, waarbij de inspecteur investeert in goede relaties met de ondertoezichtgestelde. Dit is zeker het geval indien het ook mogelijk is om een relatie op te bouwen met de ondertoezichtgestelde, omdat het een stabiele bedrijfstak betreft met bedrijven die in ieder geval de ambitie hebben om langer actief te zijn in de branche. Zijn de normen scherper, en is de inspecteur voor de constatering van de overtreding of een beter naleefgedrag minder afhankelijk van de overtreder, dan biedt dat de ruimte voor een repressieve stijl. Dit hangt samen met aantallen (geconstateerde) overtredingen en vluchtigheid van de bedrijfstak, met een open groep normadressaten. Het meest uitgesproken voorbeeld betreft de handhaving in het domein goederenvervoer over de weg en het domein Bus/taxi voor wat betreft de taxibranche, waarbij rij- en rusttijden en beladingsvoorschriften sterk repressief worden gehandhaafd.

Deze verschillen laten zich niet eenvoudig uniformeren. Juist daarom is er geen grond om te veronderstellen dat sprake is van ontdubbeling indien inspecties worden geclusterd in één grote rijksinspectiedienst. Er is geen grond om aan te nemen dat de aangetroffen variatie in de case van de IVW anders is dan de variatie voor de nieuw gevormde inspecties, zoals de Autoriteit Consument en Markt, de Nederlandse Voedsel en Warenautoriteit of de Inspectie Leefomgeving en Transport. In alle gevallen is sprake van een samenvoeging van verschillende domeinen, met contextspecifieke kenmerken ten aanzien van normering en naleefgedrag van de ondertoezichgestelden. Dat maakt een uniforme handhavingsstrategie, laat staan een uniforme handhavingsstijl, een onrealistisch doel. Als een samengevoegde inspectie als de IVW 10 jaar na de samenvoeging nog altijd een variatie laat zien in handhavingsstijlen, waarom zou dat voor andere samengeklonterde inspecties anders zijn?

\section{Noten}

1 Kamerstukken II 2010/11, 31 490, nr. 54.

2 Regeerakkoord VVD-CDA (Rutte I), 30 september 2010, p. 5 .

3 Zie: Kamerstukken II 2010/2011, 33 186, nr. 3 (Memorie van Toelichting). 
4 Zie: het Uitvoeringsprogramma compacte rijksdienst, Kamerstukken II 2010/11, 31 490, nr. 54 .

5 Uitvoeringsprogramma compacte rijksdienst, Kamerstukken II 2010/11, 31 490, nr. 54.p. 7 .

6 WRR, Toezicht op publieke belangen, Amsterdam University Press, Amsterdam 2013, p. 86.

7 Dit is een probleem dat zich niet beperkt tot Nederland of de (juridische) discipline, maar is vaker opgemerkt voor sociologisch of bestuurskundig onderzoek. Zie: Peter J. May \& Raymond J. Burby, 'Making sense out of regulatory enforcement', Law \& Policy 1998 (20), 2, p. 157-182. Zie overigens ook: WRR, Toezicht op publieke belangen, Amsterdam University Press, Amsterdam 2013, p. 37 r.b.

8 J. de Ridder, Een goede raad voor toezicht (oratie Groningen), Den Haag: Boom Juridische uitgevers 2004; H.B. Winter, Zicht op toezicht? (oratie Groningen), Groningen 2010, p. 7-8.

9 Zie titel 5.2 Awb (Toezicht op de naleving). Interbestuurlijk toezicht (titel 10.2 Awb: Toezicht op bestuursorganen) valt dus buiten het bestek van dit onderzoek.

10 Vergelijk de titel van hoofdstuk 5 Awb (Handhaving) en daarbinnen titel 5.2 (Toezicht op de naleving).

11 Het aantal stelsels met een bestuurlijke boete beslaat inmiddels meer dan 80 . Zie: H.E. Bröring, M. den Uijl, A. Tollenaar, N.J.M. Kwakman en B.F. Keulen, Referentiekader geldboetes, Verslag van een onderzoek naar de hoogte en wijze van berekening van geldboetes in het bestuursrecht en het strafrecht, Groningen: Vakgroep Bestuursrecht \& Bestuurskunde 2012.

12 Zie art. 257a Wetboek van Strafvordering.

13 M. Lipsky, Street-level bureaucracy: dilemmas of individual public services, New York: Russell Sage Foundation 1980. Voor Nederlands onderzoek naar ambtelijke beleidsvrijheid: A.B. Ringeling, Beleidsvrijheid van ambtenaren: het spijtoptantenprobleem als illustratie van activiteiten van ambtenaren bij de uitvoering van beleid (dissertatie Nijmegen), Alphen aan den Rijn: Samsom 1978. Over de relevantie van Lipksy in de moderne tijd: Taco Brandsen, Mirjan Oude Vrielink \& Liesbeth Collignon, 'De hernieuwde relevantie van Lipsky's werk', Bestuurskunde 2012 (3), p. 46-56.

14 Chris Coolsma \& Mark Wiering (red), Handhaving in stukken, Amsterdam: SISWO 2001, p. 24.

15 R.A. Kagan, 'Understanding Regulatory Enforcement', Law \& Policy 1989 (11), 2, p, 89-119.

16 M.V.C. Aalders, Regeltoepassing in de ambtelijke praktijk van Hinderwet- en Bouwtoezichtafdeling, Groningen: Wolters-Noordhoff 1987.

17.V.C. Aalders, Regeltoepassing in de ambtelijke praktijk van Hinderwet- en 
Bouwtoezichtafdeling, Groningen: Wolters-Noordhoff 1987, p. 17.

18 Peter J. May \& Raymond J. Burby, 'Making sense out of regulatory enforcement', Law \& Policy 1998 (20), 2, p. 157-182.

19 Zie over de relevantie van handhavingsstrategieën: Peter J. May \& Raymond J. Burby, 'Making sense out of regulatory enforcement', Law \& Policy 1998 (20), 2, p. 162 en J.G. van Erp, W. Huisman, H.G. Van de Bunt \& P. Ponsaers, Toezicht en compliance, Tijdschrift voor Criminologie 2008 (50) 2, p 83-95.

20 Programma Vernieuwing Toezicht, Meer effect, minder last, Den Haag: Bureau Inspectieraad 2009, p. 4. Over de precieze indeling van toezichtsdomeinen kan men van mening verschillen. Zie bijvoorbeeld het Inspectieloket (een samenwerkingsverband van verschillende rijksinspecties) voor een indeling (www.inspectieloket.nl) die afwijkt van de indeling die de IVW zelf hanteert.

21 De IVW oefende ook toezicht uit in het domein 'water'. Deze handhavingsactiviteiten hadden veelal de vorm van bestuurlijk toezicht op andere bestuursorganen, zoals waterschappen. Gelet op dit afwijkende karakter is dit domein buiten beschouwing gelaten.

22 De directe aanleiding van dit onderzoek was de veronderstelling van enerzijds het 'moederministerie' (destijds het ministerie van Verkeer en Waterstaat) en anderzijds de IVW zelf, dat er - nog altijd - grote verschillen bestonden tussen de verschillende toezichtsdomeinen, zowel voor wat betreft het instrumentarium als voor wat betreft het gebruik van dit instrumentarium. Bovendien werd verondersteld dat er domeinspecifieke rechtvaardigingen bestonden voor deze verschillen. Aan de hand van een documentenstudie, aangevuld met interviews met wetgevingsjuristen en interviews met inspecteurs is gereconstrueerd over welke instrumenten de inspectie beschikt en hoe deze worden toegepast. Het onderzoek is afgerond in 2011.

23 Dit is het gevolg van het feit dat het bij wetten die scheepvaart regelen, om Rijkswetgeving gaat, die zich niet eenvoudig laat wijzigen. Zie art. 3 aanhef en onder e van het Statuut voor het Koninkrijk der Nederlanden.

24 Zie met name het Meerjarenplan 2010-2014, te vinden op: http://www.ilent.nl/Images/MJP2010-2014\%20(def)_tcm334-319351.pdf.

25 Over cooperatieve versus punitieve handhaving: John T. Scholz, 'Cooperative Regulatory Enforcement and the Politics of Administrative Effectiveness', American Political Science Review 1991, 85 (1), p. 115-136, Peter J. May \& Raymond J. Burby, 'Making sense out of regulatory enforcement', Law \& Policy 1998 (20), 2, p. 157-182; P. Ponsaers \& B. Hoogenboom, 'Het moeilijke spel van wortel en stok', Tijdschrift voor Criminologie 2004 (46), p. 165-181 en W. Huisman, Tussen winst en moraal. Achtergronden van regelnaleving en regelovertreding door ondernemingen (diss Rotterdam), Den Haag: Boom Juridische uitgevers 2001, p. 366-367.

26 Zie: Henk van de Bunt, Judith van Erp \& Karin van Wingerde, 'Hoe stevig is de piramide van Braithwaite?', Tijdschrift voor Criminologie 2007 (49), p. 386399 en de oorspronkelijke piramide: I. Ayres \& J. Braithwaite, Responsive 
regulation: transcending the deregulation debate, New York: Oxford University Press 1992, p. 35.

27 Zie art. 5.4 Wet wegvervoer goederen en art 7 Wet havenstaatcontrole.

28 De Arbeidstijdenwetgeving en de Arbeidsomstandighedenwet wordt niet gehandhaafd door de IVW in de domeinen Spoor, Luchtvaart en Scheepvaart. Het gaat dus vooral over de handhaving in de domeinen Goederenvervoer over de weg en Bus/taxi.

29 Slechts bij hoge uitzondering wordt via een last onder dwangsom geïntervenieerd. Zie de casus waarin Prorail een last onder dwangsom werd opgelegd: Kamerstukken II 2010/11, 29 984, nr. 265

3o Henk van de Bunt, Judith van Erp \& Karin van Wingerde, 'Hoe stevig is de piramide van Braithwaite?', Tijdschrift voor Criminologie 2007 (49), p. 394 wijzen ook op de relevantie van deze factor.

31 Vergelijk F.E. Six, 'Vertrouwen in toezicht', Tijdschrift voor Toezicht 2010 (1), p. 17 e.v. 